\title{
Vertical dance: a tool for producing new social spaces \\ Lawrence, Kate
}

\section{Choreographic Practices}

DOI:

10.1386/chor.10.1.91_1

Published: 01/05/2019

Peer reviewed version

Cyswllt i'r cyhoeddiad / Link to publication

Dyfyniad o'r fersiwn a gyhoeddwyd / Citation for published version (APA):

Lawrence, K. (2019). Vertical dance: a tool for producing new social spaces. Choreographic Practices, 10(1), 93 - 113. https://doi.org/10.1386/chor.10.1.91_1

\footnotetext{
Hawliau Cyffredinol / General rights

Copyright and moral rights for the publications made accessible in the public portal are retained by the authors and/or other copyright owners and it is a condition of accessing publications that users recognise and abide by the legal requirements associated with these rights.

- Users may download and print one copy of any publication from the public portal for the purpose of private study or research.

- You may not further distribute the material or use it for any profit-making activity or commercial gain

- You may freely distribute the URL identifying the publication in the public portal ?
}

Take down policy

If you believe that this document breaches copyright please contact us providing details, and we will remove access to the work immediately and investigate your claim. 


\section{Vertical dance: A tool for producing new social spaces}

Kate Lawrence, Bangor University

\section{Abstract}

Henri Lefebvre proposed that in order to improve our lives we need to change space. Drawing on Marxist ideas of production he developed a triadic theory of space, which he proposed could be brought together through the lived experience of the body, in particular, the dancing body (1974:205). In response, I present a vertical dance manifesto that invites us to look up and imagine dancing on the walls above us and to realize this ambition by talking to people and persuading them that occupying vertical spaces might change how we experience and perceive the urban landscape. I draw upon fifteen years of practicing vertical dance (a hybrid dance form that brings together dance and the equipment of rock climbing), extended research into sitespecific practices, my Ph.D. thesis (2017) and three works I created in Belfast between 2009 and 2011. My ideas about relationships between bodies and buildings in public spaces are underpinned by Michel de Certeau's contention that 'space is practiced place' (1984: 117/118), by site-specific discourse in the arts (Kwon, 2004; Lacy, 1995 and Kaye, 2000) and recent research on site-specific dance (Hunter, 2015 and Kloetzel and Pavlik, 2009).

\section{Keywords}

space

place

vertical dance

dance 
site-specific

performance 
I have been practicing vertical dance - a hybrid dance form that takes place off the ground and uses climbing equipment to suspend dancers - since 2002, through choreographic, pedagogic and theoretical explorations. ${ }^{1}$ Building on Lefebvre's concepts of the production of social space ([1974] 1991) and site-specific discourse in the arts, I propose that vertical dance presents a means to disrupt dominant forms of spatial practice in everyday life and simultaneously to foster new and potentially beneficial relationships between bodies and buildings. Enshrined in a manifesto, my argument is illustrated by three choreographic works produced in Belfast, Northern Ireland between 2009 and 2011.

\section{Vertical Dance Manifesto}

\section{LOOK UP!}

Take a deep breath...

Choose a wall to dance on

Share your vision with people ...make it happen

use rock climbing or industrial access equipment to keep you safe

\section{LOOK DOWN}

at where you started

Is someone watching you?

Talk to them

Come back and do this again...and again...and again

Look for other vertical dance floors and invite people to join you

Join the movement to inhabit vertical space

experience the world from a different perspective produce new social spaces

use your body to remind the built environment about nature

\section{LOOK UP!}


Manifestos are statements that aim to change the status quo with a vision for a new future (Cull and Daddario 2013). Isadora Duncan's 1903 lecture 'The Dance of the Future' describes a vision of a new dance for women, aligned with nature (in Zavrel, 2002). Yvonne Rainer's No Manifesto (1965) aimed to revolutionize dance and reduce it to its essential elements. One Dance UKs Manifesto makes a case to politicians for the values and benefits of dance in the lead up to the UK General Election (2017). This manifesto's philosophical aim is to change perceptions of social and architectural space through the actions of the body. It asks people to talk to each other in order to make the apparently impossible - walking on walls achievable through negotiation and requires vertical dancers 'to embody its movement' (Cull and Daddario 2013:18). Politically, this manifesto ascribes to 'twenty-first century socialism' proposed by the Freee [sic] art collective, the goal of which is 'full human development [...] built with the people in which, as they transform their circumstances, they transform themselves and the roles they can occupy [...] it is produced actively and collectively through innovative practices' (Harnecker in Cull and Daddario 2013: 80).

The regular artistic occupation of often ignored vertical public spaces, the spaces above our heads, is the result of a delicate network of agreements between a range of people who sanction this apparently purposeless activity because they share a vision that it is worthwhile. The worthiness of the activity lies in the real and repeated manifestation of an apparently impossible action - dancing on walls - that releases the disruptive power of the physical body over the functional plans of architecture and celebrates a re-positioning and valorizing of embodied practices in the built 
environment, re-inserting nature into the urban fabric. My use of the term 'nature' refers to a vital life force located in the body/mind of the dancer that has a reciprocal relationship with the surfaces of its environment (Stewart, in Hunter, 2015: 371) and can, like the weeds that push through cracks of buildings, assert its presence in urban space.

\section{Dancing on walls}

Walls are critical for the practice of vertical dance. The politics of social space becomes more palpable through encounters between the soft, biological, permeable body of the dancer and the solid, hard structures of property. The passage of dancers' feet on the wall of an institution draw attention to the solidness of the barrier, so solid that it can withstand the wrecking ball actions of dancers, and indeed, the dancer is grateful for this solidity. Walls are transformed, temporarily, into vertical stages, raised up from the ground; transferred from the dark internal space of the theatre into the light of day; from a contained space into the fabric of a re-imagined public space. These vertical stages are not framed by proscenium arches; their edges are less pronounced, where the surface disappears around a corner vaguely indicates the end of the dancing space. They exist in the everyday, so that performing dance is part of the performance of daily life, to be witnessed for free or ignored. There are no special effects, no blackout, no lighting (except the light of the sun), no designated place to watch from, no protection from the weather, no filtering out of the sounds of the city. There is no indication that dancing on the walls of buildings should be viewed as out of the ordinary, except in how it effects the dancer's body, allowing her to appear to fly, and consequently the viewer's body, encouraging them to look up. Out of this field of negatives, the lived experience of 
the body is re-inserted into everyday life in a way which changes spatial perception without framing the body as spectacular in theatrical terms, de-familiarizing the everyday, within the everyday. Refusal to frame the performance space ${ }^{2}$ as extraordinary renders the dancers more human, less spectacular and more approachable. Although their bodies are usually out of reach, glances, words and gestures can be exchanged between performers and spectators, encounters which connect two worlds on two different planes. This very ordinariness of exchange and asides exaggerates the extraordinariness of the activity of dancing on a vertical wall.

\section{Vertical dance and spatial perception}

As an emerging performance practice that takes places off the ground, vertical dance gives rise to new physical techniques and perceptions of space for dancers and viewers of the dance. Physically, dancers develop strong 'core' muscles in order to balance on vertical 'floors' and perceptually, they resist the upright in order to stand horizontally on walls. Viewers are often seen inclining their heads in order to reframe the dancer 'the right way up'. ${ }^{3}$

In 1959, seminal postmodern dancers, including Trisha Brown, gathered for Anna Halprin's six-week workshop in Marin County, California. ${ }^{4}$ Halprin suggested working with the choreographic idea of 'task', 'such as sweeping with a broom - an ordinary action [...] performed as if you were not performing, but off alone somewhere, sweeping up' (Brown in Livet 1978: 44). Some years after her experience with Halprin, Trisha Brown created a series of works called 'equipment pieces' (Livet, 1978: 51), using apparatus to alter the viewer's perception of the body in space. The exploration of everyday movement was a major preoccupation for the postmodern 
dancers at Judson Church in New York in the 1960s and 1970s, and Brown was at the forefront of explorations on vertical planes. ${ }^{5}$ For Planes (1968), Brown built a wall with holes in it, that the dancers could climb on, onto which she projected a film of aerial footage. She said 'the audience's perception was altered. The back wall of the stage became like the floor of the auditorium' (Brown in Livet 1978: 515). Floor of the Forest (1969), her second equipment piece, involved a horizontal climbing frame constructed from ropes threaded with clothes. The dancers travelled above the heads of the audience, using the clothing as their support, like harnesses, effectively dressing and undressing as they progressed. ${ }^{6}$ Brown's intention was to present 'a normally vertical activity performed horizontally and reshaped by the vertical pull of gravity' (ibid.: 51). The third work, that is most often cited by vertical dancers as pioneering, is the eponymous Man Walking Down the Side of a Building (1970) ${ }^{7}$. A man walks, as naturally as possible, suspended in a harness facing the ground, down the wall of a building.

Brown's interest in making the unnatural appear utterly natural in order to alter the viewer's spatial perception (and presumably also that of the performer) is a fundamental aspect of vertical dance evident in the work of subsequent vertical dance artists. In 1987, French pioneering company Roc in Lichen created Le Creux Poplité, which was performed on a bathroom structure installed half way up a 500metre towering rock face in the Verdon Gorge in South Eastern France. Critic Anna Kisselgof commented of a reprise of the work in 1990, 'imagine a couple rolling around on a bathroom floor [...] then imagine that this "floor" is actually an upright wall' (Kisselgof 1990:19). San Francisco-based company Bandaloop, who are well known for making choreography for skyscrapers and huge rock faces, describe their 
work as 'perspective-bending dance' (Bandaloop Company Website 2018: n.pag.). Venice-based Wanda Moretti, who has developed an extensive training programme specifically for vertical dance, says that 'the dancer's perception of the body in space is deconstructed. She must reconstruct everything she knows in the horizontal plane in the vertical plane using other senses, other muscles, and of course this changes the gestures' (in Lawrence and Moretti 2006: 21). According to Amelia Rudolph, director of Bandaloop, 'when a person sees the front of a library as a dance floor [...] instead of simply a library...that person may begin to ask questions about her other assumptions' (in Bernasconi and Smith 2008: 58). This is how vertical dance produces the potential for imagining and enacting new social spaces in which new perceptual positions can emerge in the spaces between body and site, the individual and the architectural. Everyday life shifts upwards, onto the walls of communal, shared public spaces, warping the habitual horizontal of urban life. The presence of dancers against solid walls thus builds new relationships between bodies and buildings and changes perceptions of space when dancing on walls and watching dancing on walls.

\section{Vertical dance and site-specific dance}

Site-specific practices have been debated at length in the visual arts (Kwon, 2004; Kester 2004; Lacy 1995; Lippard 1997) and in theatre (Pearson 2010; Pearson and Shanks 2001; Birch and Tompkins 2012; Lavender 2016; Alston 2016; Kaye 2000; Wilkie 2004) and have received attention in dance studies with recent publications of edited collections of essays (Kloetzel and Pavlik, 2009; Hunter, 2015; Schiller and Rubidge, 2014). Interviews with and articles by two vertical dance choreographers, Joanna Haigood and Jo Kreiter in Kloetzel and Pavlik's Site Dance (2009) attest to 
the affinities between these two forms of dance. Their work reveals how vertical dance produces new social spaces through processes involving elements such as collaboration and careful attention to the context of production. Haigood's choreography is developed through extended research into the historical and mnemonic structures of a site to retrieve hidden, often submerged histories which then emerge in her work in an 'impressionistic' manner (in Kloetzel and Pavlik 2009: 55). In Ghost Architecture (2003) she re-inserted an ephemeral architecture into the Yerba Buena Arts Centre in San Francisco to remind viewers of the Hotel and Picture House that were lost when the Centre was created (Kloetzel and Pavlik 2009: 60). Kreiter's work has a specifically feminist agenda and she is expressly interested in 'bringing an audience to the exact place where an issue, conflict or need lives' (in Kloetzel and Pavlik 2009: 239). Mission Wall Dances (2002) took place on an incomplete mural commissioned by Kreiter's company to commemorate the deaths of fourteen people in an arson fire in 1975 (Somdahl-Sands 2008: 335). The event was designed to connect with local people's memories of the event and to raise the issue of gentrification that was impacting access to low-cost housing for local citizens. The work of both choreographers emerges from their intimate and extended exploration of the socio-political history of the site and its community.

In contrast, sculptor Richard Serra's Tilted Arc (1981-89) consisted of a massive 'wall' installed across Federal Plaza in New York, obstructing the most efficient pathway for pedestrians, forcing them to confront and negotiate the sculpture, which they ultimately rejected. It was removed in 1989 prompting Serra's famous statement: 'to move the work is to destroy the work' (in Kaye 2000: 2). A less extreme modification of everyday public behaviour occurs during rehearsals and 
performances of vertical dance. Cordoning off areas below dancers for health and safety purposes causes minor modifications to public passages through space and the presence of dancers on walls, if noticed, lifts the public gaze. Serra's avowed artistic aim was to deliberately counter-act what he perceives to be the utilitarian nature of urban design and architecture by inserting something that restructures 'conceptually and perceptually the organization of the site' (in Kwon 2004: 73). The presence of a dancer's body on the wall of a building performs a similar function by re-assigning or extending the function of an existing space: a wall temporarily becomes a dance floor.

In contrast to Serra, New genre public artists writing in Lacy's eponymous collection (1995) critique traditional models of public art production that often result in sculptures and monuments in parks and public plazas. Instead, artists such as Suzanne Lacy, Judith F. Baca and Guillermo Gómez- Peña see the role of the artist as a socially responsible and politically driven agent of change, engaging directly with communities about issues that matter to them. A relevant example here is Baca's Great Wall of Los Angeles, a half-mile long mural following the path of the concreted Los Angeles River, painted over a period of nine years by a group of over 350 inner city youths, depicting the hidden histories of women and marginalized minority communities (in Lacy, 1995). Patricia Phillips asserts that 'public art needs to be more a modest, transitional, revisable, and sustained activity in communities' (in Lacy 1995: 69). What she proposes, and I concur, is 'collective exploration' of the 'instrumentality of art' (Lacy 1995: 69). Kloetzel and Pavlik refer to such modes of collaborative, process-oriented choreography as 'attending to place', requiring a 'sustained commitment' to 'art-making and the community-place interaction' (2009: 
7). Thus, the vertical dance manifesto calls for danced inscriptions of vertical spaces achieved over time, through collaboration and negotiation. The work of Haigood and Kreiter is clearly deeply embedded in the locales in which they live and concerned with raising awareness of local socio-political concerns through collaboration with local communities. My company has danced on the exterior walls of Venue Cymru in the Victorian seaside town of Llandudno, Wales for four years and during this time we have held public workshops, established three youth groups, rehearsed and performed. We are accepted as vertical 'tenants' now, but our first appearance on the roof of the building in 2012 involved lengthy negotiations with the council health and safety officers who were highly suspicious of our proposals and understandably nervous about our safety. Our regular dancing presence in an initially surprising place, the wall of a council-run theatre, by the box office, reveals a collaborative relationship with the institution that has sanctioned this activity and signals that making artwork in public is possible, and sustainable. We have not changed civic space in material ways, but the images we create proclaim space as something we have the power to change by using our bodies in ways that disrupt the everyday, within the everyday. Michel de Certeau's analysis of the Practice of Everyday Life (1984) draws attention to the socio-political aspects of space and how it might be changed. His assertion that 'space is practiced place' (1984: 117/118) places emphasis on human movement and action relevant to this discussion. Similarly, Lefebvre's application of Marxist ideas of production to an analysis of space proposes that social space is produced - a notion that chimes with my experience of the effects of vertical dance in public spaces, wherein new connections are made between the actions of bodies standing on walls and bodies standing on the ground. Repetitive occupation of everyday spaces by vertical dance interventions 
strengthens these connections and increases our potential to change social space (Wickstrom in Cull and Daddario 2013: 48).

\section{Lefebvre's conceptual triad of space}

Lefebvre proposes three interconnected ways to understand space ([1974] 1991: 33): spatial practice, representations of space and representational space.

Spatial Practice is governed by what we perceive; the body is used to decipher space according to established social codes and conventions. In vertical dance, this means that the body must acquire physical knowledge through training and use appropriate equipment to enjoy dancing on walls safely.

Representations of Space are abstract conceptual processes often resulting from and in dialogue with spatial practice, and include plans, designs and maps. Gaining permission to dance on the wall of a building is commonly negotiated using conversation, method statements, risk assessments, assurances of technical knowledge and physical expertise and, of course, proof of insurance cover, all examples of representations of space. Each new vertical dance proposition develops and refines these tools, a process through which spatial practices (dancing and negotiating dancing) are perpetually enriched by conceptualizations of previous experience; iteration leads to consolidation.

Representational Space is 'dominated and passively experienced space which the imagination seeks to change and appropriate' through lived experience (Lefebvre 
[1974] 1991: 39). Walls are temporarily appropriated by vertical dancers, who change their function by dancing on them. Representational space 'overlays physical space' (by dancing), 'making symbolic use of its objects' (walls and buildings). Choreographic order is imposed fleetingly on existing representations of space (buildings), that are the dominant material productions of architects and urban planners in social space. Like graffiti, vertical choreography expresses new points of view during its passage across architectural surfaces, generating new meanings, not least of which is the metaphorical concept fundamental to vertical dance practice, that the wall is a floor. ${ }^{8}$

\section{Fly Butterfly (2009): Dividing walls and nature}

Figure 1

The segregation of Catholic/Unionist and Protestant/Loyalist communities in Belfast (and other cities and towns across the north of Ireland) intensified in the 1970s and 1980s in response to the Northern Ireland 'Troubles', during which 17 miles of 'peace lines' were erected in Belfast city (Plöger, 2007:14). Historically, certain walls in Belfast functioned as a symbol and means of separation, with a simultaneous function to keep the peace. Belfast was clearly starting a process of change when I worked there in 2009: some 'peace walls' have since been pulled down and Stormont (which is currently not sitting) has committed to removing them all by 2023. The divide has perhaps shifted: a younger generation no longer see the need for the barriers, whilst an older generation insist they are necessary for their protection (Anon., 2018). This shift of opinion amongst the younger generation is perhaps due to the efforts of initiatives such as the Belfast Interface Project (2007), which exists to 
encourage projects which foster 'safe, common, civic space for all' (Goldie and Ruddy 2010: 8) and develop creative approaches to the regeneration of 'interface' areas where communities from both sides of the political divide reside..

Fly Butterfly (2009) was devised and managed by The Beat Initiative, an independent carnival arts company and charity, which, like The Interface Project, is committed to bringing communities together. The project had underlying aspirations that were ambitious and wide-ranging, including contributing to the Peace process in the region (SEUPB n.d.) and seekiing to redefine a space of fortification as one of freedom, peace and hope, by employing symbols of rebirth in nature (caterpillars turning into butterflies) and by occupying the streets and walls of the city centre. My role was to train performers and choreograph the final dance on the walls of City Hall. Unlike Haigood and Kreiter, I was a stranger in the city, without any personal experience of its history or connections to its culture and I wondered about the significance of nature and rebirth as themes.

When the shoots of new plants push through cracks in the walls of buildings, this evidence of the life force of nature can be interpreted as a sign of neglect. How, then, should we respond to a similar emergence of human bodies (perhaps representing nature), dancing on walls? Are they indicative of civic anarchy, or do they provide new ways to celebrate the potency of lived experience in urban space? Lefebvre says that civic spaces, such as cathedrals, are 'confiscated from nature' ([1974] 1991: 49), a view that harbours a nostalgia for the past and a regret for the disappearance of nature, that has been criticized as espousing an originary, romantic view that disempowers nature as a force (Unwin 2000; Light and Smith 
1998) and in which 'nature is on the verge of becoming a corpse at the behest of abstract space' (Smith, 1998: 59). Therefore, to dance on a wall, is to dance on a confiscated space, to re-insert nature (as a powerful life force) into the built environment through the actions of the body, and to build new relationships between bodies and bricks.

Figure 2

The Fly Butterfly parade was fronted by a huge articulated caterpillar that snaked through the streets before arriving at Belfast's City Hall. Two dancers wearing caterpillar costumes ascended the building from the ground, whist two more dancers descended from the roof, rotating, squirming and twisting, as if trying to escape from a chrysalis. They met half way and performed a joyous celebratory dance, using the pendulum of the rope to amplify their movement. Tethered to the roof, four dancers wearing huge butterfly wings framed a mechanical butterfly. Their upper bodies and arms swayed, undulated and quivered as they embodied delicate hopes for a peaceful future. The dancers on the wall embodied the struggle for peace: the effortful ascent of the building and escape from a chrysalis, followed by the explosion of joyful expression of hope for the future expressed in the flight of the dancers over the monumental architecture of City Hall.

Belfast born dancer Sarah MacKeever's said she had a 'great sense of pride and ownership of the building' (e-mail correspondence 2015) and the Lord Mayor of Belfast, Naomi Long's assertion that 'our programme of public celebrations is in keeping with the ethos of 'a City Hall for All' (in O'Hara 2009: n.pag.). These 
statements and the Beat's vision reveal a belief that the perception of a place can be changed through human action. The presence of dancers on the exterior of the City Hall building proclaims that citizens can claim ownership of public space, for short period of real time, but perhaps for much longer in the memories of the citizens.

The land around City Hall contains commemorative statues including an enormous centrepiece memorial to Queen Victoria; signs and symbols of ownership, governance and the Crown, gathered into a 'monumental whole' (Lefebvre [1974] 1991: 224). Architecture student and blogger Molloy remarks on the marked absence of any official city centre memorials to the 1527 deaths in Belfast during The Troubles (2013). Perhaps it is too soon to consider how the victims of this recent period of violence could be acknowledged. Indeed, Plöger comments on efforts at regeneration in the city centre, that 'possibly the biggest achievement was to turn the city centre into a "neutral space"' (2007: 22). When I witnessed the presence of large crowds gathered at City Hall in a spirit of celebration of renewal and rebirth, the space seemed energized and transformed by this collective human presence.

\section{Figure 3}

\section{Off the Wall (2010): Producing social space}

Off the Wall (2010), commissioned by Circus Bone Idle, and funded by Arts Council of Northern Ireland, was designed to develop the skills of the performers who had taken part in Fly Butterfly (2009). My role was to facilitate a production based on their creative ideas to celebrate the re-opening of the Crescent Arts Centre after renovation. The Crescent Arts Centre's social history marks it variously as a site of education recognized by royalty, an unoccupied building, then a place for the community, almost lost and regained through the efforts of the community, supported 
by the House of Lords (Lord Hylton 1987: 194). Far from being a 'prosaic' and functional place, designed for service (Lefebvre [1974] 1991: 227), the history of the Crescent suggests that it is a place of the people, for the people.

The windows of the building provided an element of depth to the cabaret-style choreography by suggesting an interior world: performers disgorged from the windows to tell different stories: gangsters escaping after a robbery, a woman chatting on the phone, a love affair commencing [...] Thus, the building became a container of imaginative journeys, of creative possibilities and opportunities. Its open windows became a metaphor for openness and communication in social space. As the human geographer Doreen Massey notes, social spaces in and through which we live 'do not only consist of physical things [...] They consist also of those less tangible spaces we construct out of social interaction' (Massey in Read, 2000: 49). Leaning out of a window to pass the time of day creates a link between inside and outside; falling out of the window underlines the drama of this link and the transitional nature of windows as objects (Lefebvre [1974] 1991: 206). Using these windows to access the wall created a sense of world away from or 'off the wall'.

The audience watched from a vacant lot next to the building, reminiscent of the 'blighted spaces' identified by the Belfast Interface Project which include unused pieces of land separating different communities (2011: 9). Unlike the crowds at City Hall who gathered on the manicured lawns amongst monuments under the watchful eye of Queen Victoria, this audience stood on rough and uneven ground, amongst rubbish and weeds. From this vantage point, they were invited to engage imaginatively and metaphorically with the performance 'as if' (Lakoff and Johnson 
1980: 5) it were a cabaret, taking place at night, under lights. To imagine they were seated at tables drinking cocktails and the sounds they were hearing were only those of the entertainment on offer, not those of the street. Architectural scholar and artist Lebbeus Woods describes vacant lots as 'left-over' or 'abandoned' spaces, that 'wait in darkness and silence, "free" of content, poised for some re-occupation' (Woods in Read, [1996] 2000: 201). He calls these spaces 'freespace' characterized by 'resistance to use in normal terms [...] spaces of strangeness, challenge, potential' (Woods in Read, [1996] 2000: 201). Belfast in 2009 was full of similar 'blighted' spaces which have arisen around interfaces as a result of The Troubles, and new efforts are being made to reclaim and refigure these no-go areas as shared spaces (Goldie and Ruddy 2010). The occupation of this space by the audience refigured it temporarily as a space in which to experience performance; and the performers reloaded it with the content of the performance.

Figure 4

It is perhaps disingenuous to consider a space free of content; undoubtedly the vacant lot has a history. The point is to point to the potential of these apparently abandoned spaces and to envision the 'strange, transformative unknown [...] within the terrain of the familiar' (Woods in Read, [1996] 2000: 202). By applying Woods' concepts and strategies to Off the Wall (2010) we can see various ways in which 'strangeness' was manifest. The walls of the building became a 'floor' to walk on, dancers 'fell' out of windows and a handstand was performed on the edge of the roof to welcome the audience. Umbrellas were uselessly held over the heads of upsidedown dancers and telephone conversations were conducted whilst dancing on a 
wall. The episodic cabaret style structure simultaneously suggested and disrupted expectations of indoor club location (lighting, decadent luxury and possible consumption of alcohol). All this contributed to an invitation to an audience to experience the world from a different perspective and collectively produce a new social space.

Figure 5

\section{Life is a Carnival (2011): Walls that protect}

This final work in the Belfast trio was commissioned by Beat Carnival to be the culmination of their carnival event in the Botanic Gardens, performed on the rear walls of Ulster Museum of Natural History. On my initial reconnaissance visit I was struck by the huge number of stuffed animals on display, prompting me to devise a narrative based on the idea that the stewards of the museum were animals disguised as humans who revealed themselves during the dance. The two-part choreography reflected the architecture of the museum: the modern brutalist architectural style with huge featureless, rectilinear concrete blocks crashes against the original Classical style, making the viewer work hard to join the two sections of the building. ${ }^{9}$ The original building was built long before The Troubles, the latter, just after they began. The harsh, solid, brutalist concrete blocks of the new wing reflect the former 'fortress' city, counterpointing the comparative softness and vulnerability of the dancers' bodies, whilst simultaneously providing splendid surfaces on which to dance. The solidity inspired confidence and the big open surfaces provided opportunities for expansive movement. 
The dance began with 'museum officials' patrolling the exterior walls with clipboards, reflecting outwards the activities of those working inside the building and making connections between the function of the building, emphasized by the brutalist architecture (where the exterior suggests the layout of the interior galleries), and the choreography. The relationship of interior and exterior in this work was metaphorical, unlike Off the Wall (2010), where the windows provided real transitional objects to connect the two worlds. The Carnival drummers signalled a shift in the choreography: the performers removed their outer layers to reveal animal print catsuits. The dancing became larger, animalistic and carnivalesque: the dancers clawed at the air and lunged at each other in a 'cat ballet', and a tiger chased a chased a 'zebra' across the walls. The cool order of a museum full of dead stuffed animals, turned inside out and policed by uniformed stewards shifted to the vibrant, dynamic 'natural' world from which the exhibits had originally been removed. The return to nature echoed the themes of Fly Butterfly, with the dancers metaphorically breathing life into dead animals. The clash of costumes, human/animal, official/carnivalesque echoed the clash of architectures reflecting the historic clash (and subsequent road to reparation and cooexistence) of cultures, nationality and religion in Northern Ireland.

\section{Walking in a contained space}

Life is a Carnival (2011) was hidden away at the back of Ulster Museum. This location rendered the event more controllable, and provided a suitable gathering place, but the power of masses of people partying in the streets was diminished. The containment of the carnival within the Botanical Gardens was undoubtedly a result of the date of the event, 24 July, in the middle of the Orange order 'marching 
season' in Belfast, which stretches from April to August. Rebecca Solnit talks about the power of walking as an active way for people to 'make their history rather than suffer it' (2000: 59); the Beat Carnival parades are celebratory, with large colourful costumes, dancing and music. Solnit comments that 'a pilgrimage makes an appeal while a march makes a demand' (2000: 58). Whilst the carnival parades are not 'pilgrimages', they do make 'an appeal' to the city for peace and reconciliation. The containment of the parade producing a circular pattern within the Botanical Gardens could be regarded a spiral replica of the line made by walking through the streets of Belfast during the Fly Butterfly parade in 2009; instead of ending at City Hall, it went nowhere. Nevertheless, as Wickstrom notes in relation to the legacy of the Occupy movement (in Cull and Daddario 2013: 39), it is important to value the gathering of people sharing 'lived experience' as a positive affirmation of a desire to move forward together, even if it happens in a more 'neutral space' (Plöger, 2007: 22). Repetition is all.

\section{Concluding thoughts}

The production of social space is revealed through the physical marking of material space, here and now. Vertical dancers try not to leave footprints on walls as this might lead to the withdrawal of access. Instead, the imprint on social space is traceable through the experiences and documentary practices of onlookers: images etched in the minds of witnesses, film and photographic images shared on social media and in the case of Kreiter's Mission Wall Dances (2002), a commissioned mural incorporating images of the dancers (in Kloetzel and Pavlik 2009: 243), all revealing the production of new spaces and contributing to the stratified layers of meanings attached to places. The inert exterior surfaces of buildings are afforded a 
sensory, human aspect. Spaces of power (town halls, cathedrals, government buildings) that organize lived experience through a set of rules and regulations, become spaces of creative action and agency.

Social space 'commands bodies' (Lefebvre [1974] 1991: 143) and the particular space of vertical dance is regulated by equipment (which governs movement, rhythm and orientation of the body) and by the gate-keepers from whom permission is sought for the use of their buildings. The Vertical Dance Manifesto proposes authorized vertical dance which has the potential to produce long-lasting, perhaps more subtle and nuanced effects in social spaces, which, alongside the more radical vertical actions undertaken by organizations such as Greenpeace, ${ }^{10}$ contributes to changes in society, but in a less spectacular, exclamatory and punctuated manner.

Perceptual and conceptual shifts in spatial practice are born in the development of shared visions and negotiated permissions to use walls as dance floors, in creative processes witnessed during rehearsals in public space and in dancers who successfully orientate their bodies on a vertical 'floor'. Dancing on walls reveals that people working in the institutions around us (cathedrals, libraries, city halls, arts centres) have the vision to validate, and the power to implement alternative uses for buildings so that the public may encounter them as creative spaces for expression. Dancers, choreographers and teachers are challenged to find and apply new spatial frames of reference to orientate their bodies in space and to communicate these. The diverse bodies that allow vertical dance to exist thus include gatekeepers of buildings (health and safety officers, building managers, engineers and architects), dancers who take a step off the roof, trusting their equipment, riggers who calculate the dynamic loads on rigging points and arts programmers who might undertake 
complex negotiations and contribute artistic ideas. Throughout my practice, I have found that vertical dance infiltrates the consciousness of the public, it fires their imaginations and changes the ways in which they view everyday spaces. For example, in 2013, composer Rob Spaull reported that a 'lady from Bolton who after stopping to watch one of the rehearsals, declared, 'Thank you so much! That was just magical, really amazing. You took me somewhere else' (e-mail feedback, 2013).

The Vertical Dance Manifesto is a concentrated, distilled version of my research, formulated as a call to action. It has a political motive: to change social space for the benefit of citizens by using the vitality of the dancing body to breathe life into the hard and solid built environment. It calls not for singular revolutionary actions, but repetitive ways of being collectively and collaboratively in space that accrete over time, gradually changing perceptions and producing new social spaces.

\section{References}

Alston, Adam (2016), Beyond Immersive Theatre: Aesthetics, Politics and Productive Participation, London: Palgrave Macmillan.

Anon. (2018) 'Will Nl's peace walls come down by 2023 to meet the 10 -year target?' BBC News, 3 May 2018. https://www.bbc.co.uk/news/uk-northern-ireland-43991851. Accessed 1 February 2019. 
Bandaloop Company Website (2018), 'Who are we?'

https://www.bandaloop.org/who-we-are/. Accessed 15 October 2018.

Belfast Interface Project (2011), Interface barriers, peacelines and defensive architecture. https://www.belfastinterfaceproject.org. Accessed 21 October 2017.

Bernasconi, Jane and Smith, Nancy (2008), Aerial Dance, Champaign, IL: Human Kinetics.

Birch, Anna, and Tompkins, Joanne (eds) (2012), Performing Site-Specific Theatre: Politics, Place, Practice, Basingstoke: Palgrave Macmillan.

Certeau, Michel de (1984), The Practice of Everyday Life, London: University of California Press.

Cull, Laura and Daddario, Will (eds) (2013), Manifesto Now! Instructions for Performance, Philosophy, Politics, Bristol: Intellect.

Flyaway Productions (2009), 'Mission Wall Dances (2002)', https://www.youtube.com/watch?v=91aHbgWGkik. Accessed 5 March 2017.

Goldie, Roz and Ruddy, Brid (2010), Crossing the Line: Key Features of Effective Practice in the development of Shared Space in areas Close to an Interface, Belfast Interface Project, 

e\%20Line.pdf. Accessed 15 January 2016.

Haigood, Joanna (2009), 'Looking for the invisible', in Melanie Kloetzel and Carolyn Pavlik (eds), Site Dance: Choreographers and the Lure of Alternative Spaces, Gainesville: University Press of Florida, pp. 60-63

Harnecker in Cull, Laura and Daddario Will (eds.) (2013), Manifesto Now! Instructions for Performance, Philosophy, Politics, Bristol: Intellect, pp 71-84.

Hiesl, Angie and Kaiser, Roland. Dressing the City and My Head is a Shirt https://vimeo.com/39887465. Accessed 15 June 2017

Hunter, Victoria (ed.) (2015), Moving Sites: Investigating Site-Specific Dance Performance, Abingdon: Routledge.

Kaye, Nick (2000), Site-Specific Art: Performance, Place and Documentation, London: Routledge.

Kester, Grant (2004), Conversation Pieces: Community and Communication in Modern Art, Berkeley: University of California Press.

Kisselgof, Anna (1990), 'Walking on the wall, or maybe it's a floor', New York Times, 2 August, https://www.nytimes.com/1990/08/02/arts/review-dance-walking-on-thewall-or-maybe-it-s-a-floor.html. Accessed 11 February 2018. 
Kloetzel, Melanie and Pavlik, Carolyn (eds) (2009), Site Dance: Choreographers and the Lure of Alternative Spaces, Gainesville: University Press of Florida.

Kreiter, Jo (2009), 'Making Sparrow's End', in Melanie Kloetzel and Carolyn Pavlik (eds), Site Dance: Choreographers and the Lure of Alternative Spaces, Gainesville: University Press of Florida, pp. 246-252.

Kwon, Miwon (2004), One Place After Another: Site-Specific Art and Locational Identity, Cambridge, MA: The MIT Press.

Lacy, Suzanne (ed.) (1995), Mapping the Terrain: New Genre Public Art, Washington: Bay Press.

Lakoff, George (1987), Women, Fire, and Dangerous Things: What Categories Reveal about the Mind. Chicago: University of Chicago Press.

Lakoff, George and Johnson, Mark (1980), Metaphors We Live By, Chicago: University of Chicago Press.

Lavender, Andy (2016), Performance in the Twenty-First Century: Theatres of Engagement, Abingdon: Routledge.

Lawrence, Kate (2009), Fly Butterfly. https://prezi.com/1sc5yzwkircj/fly-butterfly/. Accessed 12 February 2017. 
Lawrence, Kate (2010), Off the Wall. https://prezi.com/1 ofhtrcaldn3/off-the-wall/. Accessed 12 February 2017.

Lawrence, Kate (2011), Life is a Carnival. https://prezi.com/o7n3u39exnuc/life-is-acarnival/. Accessed 14 February 2017.

Lawrence, Kate (2017), 'Up, down and amongst: Perceptions and productions of space in vertical dance practices', Ph.D. thesis, Guildford: University of Surrey, http://epubs.surrey.ac.uk/845092/1/Kate\%20Lawrence\%20PhD\%20final\%20upload. pdf. Accessed 11 July 2018.

Lawrence, Kate and Moretti, Wanda (2006), 'Vertical dance with Wanda Moretti', Dancing Cities: Dance in Urban Landscapes, December 2006, p. 21.

Lefebvre, Henri ([1974] 1991), The Production of Space, Oxford: Blackwell.

Light, Andrew and Smith, Jonathan (eds) (1998), Philosophy and Geography II: The Production of Public Space, Maryland: Rowman and Littlefield.

Lippard, Lucy (1997), The Lure of the Local: Senses of Place in a Multi-Centred Society, New York: The New Press.

Livet, Anne (ed.) (1978), Contemporary Dance, New York: Abbeville Press. 
Lord Hylton (1987), 'Appropriation (No. 2) (Northern Ireland) Order 1987', Hansard:

House of Lords, http://hansard.millbanksystems.com/lords/1987/jul/16/appropriationno-2-northern-ireland. Accessed 6 September 2017.

Massey, Doreen (2000), 'Space-time and the politics of location', in Read, Alan (ed.), Architecturally Speaking: Practices of Art, Architecture and the Everyday, London and New York: Routledge, pp. 49-63.

McKeever, Sarah (2015), e-mail to author, 5 September 2015.

McKittrick, David (1992), 'Belfast Security Measures accepted as normal: People in Belfast have become accustomed to police checks and the "ring of steel" which protects the city's commercial heart', The Independent, 7 December.

https://www.independent.co.uk/news/uk/belfast-security-measures-accepted-asnormal-people-in-belfast-have-become-accustomed-to-police-1562036.html. Accessed 12 October 2018.

Molloy, Andrew (2013), 30 January, 'Pass over in silence' http://passoverinsilence.blogspot.co.uk/2013/01/forgetting-belfast.html. Accessed 5 February 2017.

O'Hara, Victoria (2009), 'Time capsule to be locked away in Belfast's City Hall', Belfast Telegraph, 16 October, http://www.belfasttelegraph.co.uk/news/time-capsuleto-be-locked-away-in-belfasts-city-hall-28499212.html. Accessed 2 May 2017. 
One Dance UK Manifesto (2017), https://www.onedanceuk.org/wp-

content/uploads/2017/04/One-Dance-UK-Dance-Manifesto-Election-2017.pdf Accesssed 1 February 2019

Pearson, Mike (2010), Site-specific Performance, Basingstoke: Palgrave Macmillan.

Pearson, Mike and Shanks, Michael (2001), Theatre/Archaeology, London:

Routledge.

Petronio, Stephen (2017) ‘5 Artists on working with Trisha Brown' in New York

Times. https://www.nytimes.com/2017/03/20/arts/dance/5-artists-on-working-with-

trisha-brown.html Accessed 1 February 2019)

Phillips, Patricia (1995), 'Public constructions', in Suzanne Lacy (ed.), Mapping the Terrain: New Genre Public Art, Washington: Bay Press, pp. 60-71.

Plöger, Jörg (2007), Belfast City Report, CASE Report 44, Centre of Analysis of Social Exclusion, ESRC Research Centre, Belfast.

Robert, Alain (2008) With Bare Hands: the story of the human spider, Dunboyne: Maverick House.

Rosch, Eleanor. and Lloyd, Barbara (eds). (1978) Cognition and categorization 2748. Hillsdale, NJ: Lawrence Erlbaum. 
Schiller, Gretchen and Rubidge, Sarah (eds) (2014), Choreographic Dwellings: Practicising Place, New York: Palgrave Macmillan.

SEUPB (n.d.), 'Peace III programme', http://www.seupb.eu/programmes20072013/peaceiiiprogramme/overview.aspx. Accessed 14 February 2017.

Smith, Neil (1998), 'Antinomies of space and nature', in Andrew Light and Jonathan M. Smith (eds), Philosophy and Geography II: The Production of Public Space, Maryland: Rowman and Littlefield, pp. 48-69

Solnit, Rebecca (2000), Wanderlust: A History of Walking, Harmondsworth: Viking Penguin.

Somdahl-Sands, Katrinka (2008), 'Citizenship, civic memory and urban performance: Mission wall dances', Space and Polity, 12:3, pp. 329-52.

Stewart, Nigel (2015) in Hunter, Victoria (ed.). Moving Sites: Investigating SiteSpecific Dance Performance, Abingdon: Routledge. Pp 364-384 Unwin, Tim (2000), 'A waste of space? Towards a critique of the social production of space [...]', Transactions of the Institute of British Geographers, 25:1, pp. 11-29.

Weingartner, Sabine (2014), 'Simone Forti', Frieze.com, https://frieze.com/article/simone-forti. Accessed 11 March 2017. 
Wickstrom, Maurya and Vella, Stephanie (2013), 'Duration and space: The new manifesto of Occupy Wall Street', in Laura Cull and Will Daddario (eds), Manifesto Now! Instructions for Performance, Philosophy, Politics, Bristol: Intellect, pp. 38-50.

Wilkie, Fiona (2004), 'Out of place: The negotiation of space in site-specific performance', Ph.D. thesis, Guildford: University of Surrey.

Wittgenstein, Ludwig (1953), Philosophical Investigations. Oxford Blackwell.

Woods, Lebbeus ([1996] 2000), 'No-man's land', in A. Read (ed.), Architecturally Speaking: Practices of Art, Architecture and the Everyday, London and New York: Routledge, pp. 199-211.

Zavrel, John (2002) 'Isadora Duncan and 'The Dance'.

http://www.meaus.com/isadora-duncan.htm. Accessed: 1 February 2019

\section{Contributor details}

Kate is lecturer in performance at Bangor University. Previously, at University of Surrey she pioneered a vertical dance module (1999-2010). Since 2010 she has produced eight vertical dance works and her 2014 work, Gwymon, presented at British Dance Edition. She has collaborated with National Theatre Wales, National Dance Company Wales, Theatr Genedlaethol Cymru, Marc Rees, Llawn Festival, Circomedia, Beat Initiative Belfast and Pflasterspektalkl Linz, producing 
choreography for building such as Belfast City Hall, Guildford Cathedral, St Nazaire submarine base, Haus der Geschichten, Linz, Bristol dock cranes, Welsh Assembly Building and National Library of Wales. Kate has written articles on site-specific performance and published the first scholarly article on vertical dance (2010). In 2017 she completed her Ph.D. and has spoken at conferences including the Royal Geographical Society Annual Conference, Performing Mountains Symposium and the AHRC Living Landscapes Conference. She is a founder member of Vertical Dance Forum.

Contact:

Bangor University, Bangor LL57 2DG, UK.

E-mail: k.lawrence@bangor.ac.uk

\section{https://orcid.org/}

Figure 1: Monumental space of Belfast City Hall with statue of Queen Victoria before the crowds entered the grounds. Photographer: Kate Lawrence.

Figure 2: Belfast City Hall with the crowds gathered to watch Fly Butterfly by Kate Lawrence for the Beat Initiative. Performers: Aaltje Cuperus, Beccy Laidlaw, Rachael Lindsey-Devenney and Natasha Wilton. Photographer: Kate Lawrence.

Figure 3: Performer looking down from the roof of Belfast City Hall as the crowds gather for Fly Butterfly. Performer: Natasha Wilton. Photographer: Kate Lawrence 
Figure 4: Dancers rehearsing on the side wall of Crescent Arts Centre, watched by passing public; vacant lot visible on the right. Dancers: Flora Herberich and Beccy Laidlaw. Photograph: Kate Lawrence.

Figure 5: 'Umbrellas uselessly held over the heads of upside-down dancers'. Dancers: Beccy Laidlaw, Sarah MacKeever, Natasha Wilton and Rachael Devenney. Photograph: Kate Lawrence

Notes

${ }^{1}$ Pedagogic activities include the development of a vertical dance module at the University of Surrey, teaching at various aerial dance festivals and most recently, running three youth vertical dance groups. Choreographic activities include twenty vertical dance works produced between 2002 and the present day. ${ }^{2}$ Vertical dance performances do frame the space to an extent: they may take place at a particular advertised time, the duration may be signaled by with music, the space below the dancers might be cordoned off for safety reasons and some performances employ lighting and projection. Rehearsals in public may not employ any of these conventions.

${ }^{3}$ For a comprehensive categorization of vertical dance see Lawrence (2017), in which I employ prototype theory of categorization developed by Wittgenstein (1953), Rosch (1978) and Lakoff (1987).

\footnotetext{
${ }^{4} \mathrm{~A}$ more comprehensive history of vertical dance can be accessed in Chapter 1 of Lawrence (2017).
} 
${ }^{5}$ Italian/American dancer and choreographer Simone Forti created a work called Slant Board in 1961, in which dancers moved up and down a board at a 45-degree angle to the ground using knotted ropes. She also studied with Anna Halprin and was exploring the 'interface of sculpture and performance' (Weingartner 2014: n.pag.). After this she concentrated on assisting her husband, performance artist Robert Whitman and when she returned to her own work, her innovative early explorations had become 'established tropes', explaining the lack of recognition she has earned (Weingartner 2014).

${ }^{6}$ An interesting re-emergence of the use of clothing as 'harness' to support the dancer may be seen in Angie Hiesl's and Roland Kaiser's 2011 collaborative work, Dressing the City and my head is a Shirt in the streets of Cologne:

https://vimeo.com/39887465.

${ }^{7}$ Man Walking Down the Side of a Building has been reprised a number of times:

Trisha Brown herself restaged it in France with Stephen Petronio performing (1982). In 2006 it was performed on the iconic tower of the Tate Modern in London. Thereafter Eliizabeth Streb preformed it in 2010 and Amelia Rudolph in 2013. Most of the recent performances were part of retrospectives of Brown's work.

${ }^{8}$ I explore the metaphorical aspects of vertical dance in Chapter 2 of my Ph.D. with reference to the collaborative work of linguist Lakoff and philosopher Johnson, Metaphors We Live By (1980).

9 The original building, designed by James Cumming Wynnes, was opened 1929. A new wing was added in 1972, designed by Frances Pym.

${ }^{10}$ See for example 2013 ascent of the Shard in London by all female team from Greenpeace to protest against oil and gas drilling in the Arctic and Alain Robert's 
autobiography (2008) discussing his solo climbing of the highest buildings in the world, sometimes in order to place a protest banner. 